\title{
PENERAPAN PEMBELAJARAN GROUP INVESTIGATION DALAM MENINGKATKAN KETERAMPILAN PENULISAN DESAIN PENDIDIKAN GEOGRAFI IKIP PGRI PONTIANAK
}

\author{
Rika Anggela ${ }^{1}$, Suherdiyanto $^{2}$, Rina $^{3}$ \\ ${ }^{1,2,3}$ Program Studi Pendidikan Geografi \\ Fakultas Ilmu Pendidikan dan Pengetahuan Sosial IKIP PGRI Pontianak \\ Jalan Ampera Nomor 88 Pontianak - 78116, Telepon (0561) 748219 Fax. (0561) 589855 \\ ${ }^{1}$ Alamat e-mail: anggela_12icka@yahoo.com
}

\begin{abstract}
Abstrak
Tujuan dalam penelitian ini untuk mendapatkan informasi secara jelas, objektif dan sistematis tentang penerapan pembelajaran Group Investigation (GI) dalam meningkatkan keterampilan penulisan desain penelitian pada mata kuliah Seminar Kuliah Geografi Semester VI IKIP PGRI Pontianak TA. 2016/2017. Penelitian ini merupakan penelitian tindakan yang dilakukan secara partisipatif. Berdasarkan hasil penelitian, diketahui bahwa penerapan Group Investigation pada siklus I dan Siklus II baik sekali. Persentase Ketuntasan kelas Keterampilan penulisan desain penelitian pada pra tindakan sebesar 38,9\%, siklus I sebesar $66,1 \%$ dan siklus II sebesar $100 \%$. Peningkatan kepercayaan diri mahasiswa mulai pra tindakan sampai pada siklus I sebesar 26,7\% dan mulai siklus I sampai pada siklus II sebesar 33,4\%.
\end{abstract}

Kata Kunci: Group Investigation, Keterampilan Penulisan, Pendidikan Geografi

\begin{abstract}
This research aims to get clear, objective, systematic information about implemetation of Group Investigation in improving university students' writing skills of research design of seminar subject in Geography study.This research is action research that is done in participative. The result of research is the implementation of Group Investigation is very good. It is seen from the first cycle and second cycle. By using Group Investigation, writing skills of research design by student in base line is $38,9 \%$, in the first cycle is $66,1 \%$ and the second cycle is $100 \%$. The improvement of students' writing skills of research design from the base line to the first cycle is $26,7 \%$ and from the first cycle to the second cycle is $33,4 \%$.
\end{abstract}

Key words: Group Investigation, writing skills, Geography Education

\section{PENDAHULUAN}

Proses pendidikan di Perguruan Tinggi memiliki tahapan-tahapan yang harus ditempuh. Sivitas akademika yang meliputi dosen dan mahasiswa memiliki kewajiban untuk melaksanakan Tri Dharma Perguruan Tinggi yaitu: 1) Pendidikan, 2) Penelitian, dan 3) Pengabdian kepada Masyarakat, yang secara jelas tertuang dalam Pasal 1 Undang-Undang Republik Indonesia Nomor 12 Tahun 2012 tentang Pendidikan Tinggi. Institut Keguruan dan Ilmu Pendidikan Persatuan Guru Republik Indonesia (IKIP PGRI) Pontianak merupakan salah satu Perguruan tinggi swasta yang memiliki program studi yang secara khusus 
mengarahkan mahasiswa untuk memiliki spesifikasi kemampuan dibidang pendidikan. Pelaksanaan Tri Dharma pendidikan secara bertahap dijalankan oleh mahasiswa melalui program-program dan mata kuliah yang harus ditempuh. Salah satu yang harus dijalankan perguruan tinggi khususnya IKIP PGRI Pontianak adalah penelitian.

Penelitian yang merupakan salah satu elemen penting dalam penyelesaian studi. Penerapan penelitian dituangkan dalam kewajiban mahasiswa untuk menulis karya ilmiah dengan Skripsi sebagai tugas akhir yang harus diselesaikan. Penyelesaian skripsi merupakan sebuah tantangan besar bagi mahasiswa khususnya Mahasiswa program studi Pendidikan Geografi. Sebelum menjadi skripsi, mahasiswa harus dapat membuat desain penelitian yang merupakan tahap awal dalam pembuatan skripsi. Desain penelitian merupakan rencana penelitian yang akan dipertahankan dalam Seminar Desain Skripsi. Tahapan ini melalui proses panjang dalam bimbingan bersama dosen pembimbing. Desain penelitian berisi segala sesuatu yang berkaitan dengan rencana penelitian yang ditulis secara sistematis dengan berlandaskan pada teori-teori yang relevan. Untuk dapat menuliskan secara jelas dan benar, mahasiswa harus menguasai teori, teknis dan tata tulis yang kaitannya dengan penelitian.

Berdasarkan observasi pada mahasiswa Geografi bahwa masih banyak mahasiswa yang harusnya pada semester ini sudah mencapai tahap seminar tetapi belum sampai tahap tersebut. Hal ini dikarenakan : 1) masih banyak yang belum berani mengangkat judul penelitian, 2) belum memahami judul penelitian yang akan ditulis, 3) belum memahami cara penulisan desain skripsi yang benar sehingga memerlukan waktu yang lama dalam bimbingan. Padahal pada kenyataannya mahasiswa tersebut telah melewati mata kuliah yang berhubungan dengan penulisan desain penelitian seperti mata kuliah Seminar Kuliah Geografi. Ini mengindikasikan bahwa mata kuliah yang telah dilewati tidak memberikan implikasi dalam keterampilan mahasiswa untuk membuat desain penelitian. Apalagi untuk mahasiswa yang belum mendapatkan mata kuliah Seminar Kuliah Geografi yaitu mahasiswa semester VI. Tentunya harus mendapatkan pembelajaran yang mendorong pada keterampilan dalam membuat desain. Melihat 
kenyataan pada semester sebelumnya mahasiswa masih belum terampil dalam membuat tulisan ilmiah seperti makalah. Terlihat sekali masih belum baik hasilnya. Mahasiswa cenderung melakukan penjiplakan dari bahan-bahan yang tersedia di media online seperti google yang sumbernya tidak dapat dipertanggung jawabkan. Jika hal tersebut kurang diperhatikan, ini akan mempersulit mahasiswa untuk memulai penulisan desain penelitian di akhir studinya.

Keterampilan merupakan bagian dari hasil belajar. Menurut Thursan Hakim, 2000 (Hamdani, 2011: 20) Belajar adalah suatu proses perubahan dalam kepribadian manusia, dan perubahan tersebut ditampakkan dalam bentuk peningkatan kualitas dan kuantitas tingkah laku, seperti peningkatan kecakapan, pengetahuan, sikap, kebiasaan, pemahaman, keterampilan dan daya pikir, dan lain-lain. Sehingga terdapat perubahan pada diri individu setelah mengalami proses belajar. Hasil belajar merupakan pencapaian bentuk perubahan perilaku yang menetap dari ranah kognitif, afektif dan psikomotoris dari proses belajar yang dilakukan dalam waktu tertentu (Jihad dan Haris, 2013: 14). Kingsley membagi hasil belajar menjadi tiga macam yaitu : 1) keterampilan dan kebiasaan; 2) pengetahuan dan pengertian; 3) sikap dan cita-cita (Sudjana, 2016: 22). Untuk memberikan solusi dalam permasalahan di atas, peneliti merencanakan untuk menerapkan pembelajaran Group Investigation (GI) dalam pembelajaran Seminar Kuliah Geografi.

Group investigation merupakan sebuah pembelajaran kooperatif yang menuntut dialog interpersonal dan dimensi rasa sosial. Intelektual dapat dibangun bersama-sama kelompok. Kelompok sebagai sumber-sumber penting bagi peserta didik untuk belajar. Oleh karena itu peran teman satu kelas yang dibagi menjadi kelompok-kelompok kecil turut andil dalam pertukaran intelektual (Slavin, 2005: 215). Dengan begitu pembelajaran ini menuntut kemandirian dari setiap mahasiswa dalam kelompoknya. Menurut pendapat Kurniasi,dkk (2015: 71) menyatakan bahwa Group Investigation (GI) menekan pada partisipasi dan aktivitas mahasiswa untuk mencari sendiri materi atau segala sesuatu berkenaan dengan materi. Informasi didapat dari bahan-bahan yang tersedia baik dari buku materi perkuliahan, perpustakaan, literatur online dan referensi lain yang dapat 
dipertanggungjawabkan kebenarannya. Sejalan dengan penelitian yang dilakukan Indajati (2017: 108) diketahui bahwa Penerapan Group Investigation (GI) efektif dalam pembelajaran, dimana dalam pembelajaran peserta didik dapat aktif dalam kegiatan diskusi antar peserta didik. Hal tersebut sejalan dengan permasalahan yang ada. Mahasiwa memerlukan kemandirian dan konsentrasi penuh dalam mencari pemecahan masalah yang berhubungan dengan penelitiannya. Dengan begitu mahasiswa memiliki pengalaman yang mampu mendorong dalam keterampilan penulisan desain penelitian.

\section{METODE}

Metode dalam penelitian ini adalah penelitian tindakan kelas (PTK) dengan bentuk penelitian adalah penelitian tindakan kelas yang dilakukan secara partisipatif. Peneliti melakukan penelitian pada mata kuliah yang diampu sendiri. Penelitian Tindakan Kelas ini dilakukan di IKIP PGRI Pontianak. Penelitian ini dilaksanakan pada Bulan Mei sampai Juni 2017. Pelaksanaan tindakan dilakukan dalam 2 (dua) siklus dengan 7 (tujuh) kali pertemuan.

Subjek dalam penelitian ini adalah mahasiswa Kelas A Sore semester VI (enam) IKIP PGRI Pontianak berjumlah 36 orang Adapun pemilihan kelas tersebut dengan alasan bahwa kelas A sore semester VI memiliki masalah yang berhubungan dengan keterampilan dalam membuat desain penelitian. Teknik pengumpulan data yang digunakan adalah teknik observasi langsung, teknik pengukuran dan studi dokumenter. Teknik observasi langsung menggunakan instrumen berupa lembar observasi yang ditujukan untuk dosen selaku pelaksana pembelajaran dan mahasiswa selaku subjek penelitian. Instrumen lain yang digunakan adalah lembar penilaian desain skripsi dan dokumentasi untuk memperoleh data dengan mengumpulkan berkas-berkas atau arsip yang dianggap penting dalam penelitian. Data yang telah diperoleh dalam penelitian ini akan dianalisis secara kuantitatif dan kualitatif. Data kuantitatif diperoleh dari hasil tes penulisan desain penelitian. Data-data yang telah diketahui tersebut dianalisis menggunakan statistika deskriptif, yaitu penghitungan angka-angka dengan menggunakan rumus statistika dan dideskripsikan. 


\section{HASIL DAN PEMBAHASAN}

Setelah melakukan 2 siklus penelitian pada perkuliahan Seminar Kuliah Geografi dengan menggunakan Group Investigation (GI) yang dilakukan oleh peneliti sendiri dengan observasi dilakukan oleh teman sejawat diperoleh hasil sebagai berikut :

\section{A. Penerapan pembelajaran Group Investigation (GI) dalam meningkatkan keterampilan penulisan desain penelitian}

Adapun hasil penerapan dapat dilihat pada tabel sebagai berikut:

Tabel 1. Penerapan Model Pembelajaran Group Investigation (GI) (Siklus I Dan II)

\begin{tabular}{cccc}
\hline Siklus & SKOR TOTAL & RATA-RATA & Ket \\
\hline I & 14,4 & 3,6 & Baik Sekali \\
\hline II & 15,6 & 3,9 & Baik Sekali \\
\hline
\end{tabular}

Adapun secara detail dapat dilihat pada tabel berikut:

Tabel 2. Penerapan Model Pembelajaran Group Investigation Per Komponen (Siklus I Dan II)

\begin{tabular}{|c|c|c|c|c|c|}
\hline \multirow[b]{2}{*}{ Siklus } & \multicolumn{4}{|c|}{ Skor Komponen Pembelajaran } & \multirow[b]{2}{*}{$\begin{array}{c}\text { Rata-rata } \\
\text { Skor }\end{array}$} \\
\hline & Pra Pembelajaran & $\begin{array}{c}\text { Membuka } \\
\text { Pembelajaran }\end{array}$ & $\begin{array}{c}\text { Kegiatan } \\
\text { Inti }\end{array}$ & Penutup & \\
\hline I & $\begin{array}{c}4 \\
\text { (Baik Sekali) }\end{array}$ & $\begin{array}{c}4 \\
\text { (Baik Sekali) }\end{array}$ & $\begin{array}{c}3,1 \\
\text { (Baik) }\end{array}$ & $\begin{array}{c}3,3 \\
\text { (Baik) }\end{array}$ & $\begin{array}{c}3,6 \\
\text { (Baik } \\
\text { Sekali) }\end{array}$ \\
\hline II & $\begin{array}{c}4 \\
\text { (Baik Sekali) }\end{array}$ & $\begin{array}{c}4 \\
\text { (Baik Sekali) }\end{array}$ & $\begin{array}{c}3,85 \\
\text { (Baik } \\
\text { Sekali) }\end{array}$ & $\begin{array}{c}3,7 \\
\text { (Baik } \\
\text { Sekali) }\end{array}$ & $\begin{array}{c}\text { 3,9 (Baik } \\
\text { Sekali) }\end{array}$ \\
\hline
\end{tabular}

Penerapan model pembelajaran Group Investigation (GI) baik sekali terlihat dari Pelaksanaan pembelajaran pada siklus I dan siklus II. Kegiatan dalam pelaksanaan pembelajaran antara lain : a) Kegiatan Pra pembelajaran. Kegiatan ini 
dilaksanakan dengan baik sekali. Guru secara cermat menyiapkan ruang, alat dan media yang akan digunakan dalam mendukung kegaiatan belajar pembelajaran, b) Kegiatan membuka pelajaran dilaksanakan dengan baik sekali. Guru melaksanakan pembelajaran dimulai dengan apersepsi, informasi dari guru ke peserta didik mengenai tujuan dan materi pelajaran, c) Kegiatan inti berjalan dengan baik pada siklus I dan Sangat Baik pada Siklus II, guru menjalankan segala kegiatan dalam inti pembelajaran dengan baik dan benar. Kegiatan inti pembelajaran merupakan kegiatan yang sangat penting karena dapat terlihat sejauh mana penerapan model pembelajaran Group Investigation (GI) dilaksanakan dalam pembelajaran, d) Kegiatan penutup dilaksanakan guru dengan baik. Guru tidak langsung menutup pelajaran namun melaksanakan tanya jawab dan merefleksi kegiatan pembelajaran yang telah dilaksanakan.

\section{B. Peningkatan keterampilan penulisan desain penelitian melalui penerapan model pembelajaran Group Investigation (GI)}

Penilaian keterampilan penulisan desain penelitian melalui penerapan model pembelajaran Group Investigation (GI) dilakukan mulai dari pra tindakan, siklus I dan siklus II. Dari ketiga siklus tersebut dilakukan perbandingan untuk dapat melihat sejauh mana peningkatan yang terjadi pada pra tindakan, siklus I dan siklus II. Adapun peningkatan keterampilan penulisan desain penelitian melalui penerapan model pembelajaran Group Investigation (GI) dapat dilihat tabel sebagai berikut :

Tabel 3. Peningkatan Keterampilan Penulisan Desain Penelitian melalui Penerapan Model Pembelajaran Group Investigation (GI)

\begin{tabular}{ccccc}
\hline Tindakan & Jumlah & Rata-rata & Nilai Min & Nilai Max \\
\hline Pra Tindakan & 1892 & 52,6 & 43 & 63 \\
\hline Siklus I & 2412 & 67 & 57 & 76 \\
\hline Siklus II & 2949 & 82 & 67 & 93 \\
\hline
\end{tabular}

Berdasarkan tabel 3 dapat diketahui bahwa terjadi peningkatan keterampilan penulisan desain penelitian. Terlihat dari rata-rata pra tindakan 
sebesar 52,6, siklus I sebesar 67 dan siklus II sebesar 82. Peningkatan yang terjadi dari Pra Tindakan ke siklus I sebesar 14,4 dan dari siklus I ke siklus II sebesar 15. Nilai terendah yang didapatkan mahasiswa pada akhir siklus (siklus II) adalah 67 dan nilai tertinggi adalah 93 tentunya terjadi perubahan yang cukup tampak dari mulai Pra Tindakan, siklus I dan siklus II. Untuk lebih jelasnya dapat dilihat pada grafik berikut ini:

\section{Gambar 1. Grafik Peningkatan Keterampilan Menulis Desain Penelitian}



Adapun nilai ketuntasan kelas pada pra tindakan, siklus I dan siklus II dapat dilihat pada tabel berikut ini :

Tabel 4. Persentase Keterampilan Penulisan Desain Penelitian (Pra Tindakan, Siklus I, Siklus II)

\begin{tabular}{ccc}
\hline & TUNTAS & TIDAK TUNTAS \\
\hline Pra Tindakan & $38,9 \%$ & $61,1 \%$ \\
\hline Siklus I & $66,6 \%$ & $33,3 \%$ \\
\hline Siklus II & $100 \%$ & $0 \%$ \\
\hline
\end{tabular}

Berdasarkan tabel 4 dapat diketahui bahwa terjadi peningkatan ketuntasan kelas dalam keterampilan penulisan desain penelitian. Terlihat dari persentase ketuntasan sebesar 38,9\%, siklus I sebesar 66,6\% dan siklus II sebesar 100. Peningkatan yang terjadi pada dari Pra Tindakan ke siklus I sebesar 26,7\% dan dari siklus I ke siklus II sebesar 33,4\%. Dengan melihat hasil penelitian dari tabel tersebut tampak bahwa pada dalam pra tindakan kelas tersebut tidak mencapai 
indikator ketuntasan sebesar $\geq 75 \%$ Untuk lebih jelasnya dapat dilihat pada grafik berikut ini:

\section{Gambar 2. Grafik Peningkatan Keterampilan Desain Penelitian}

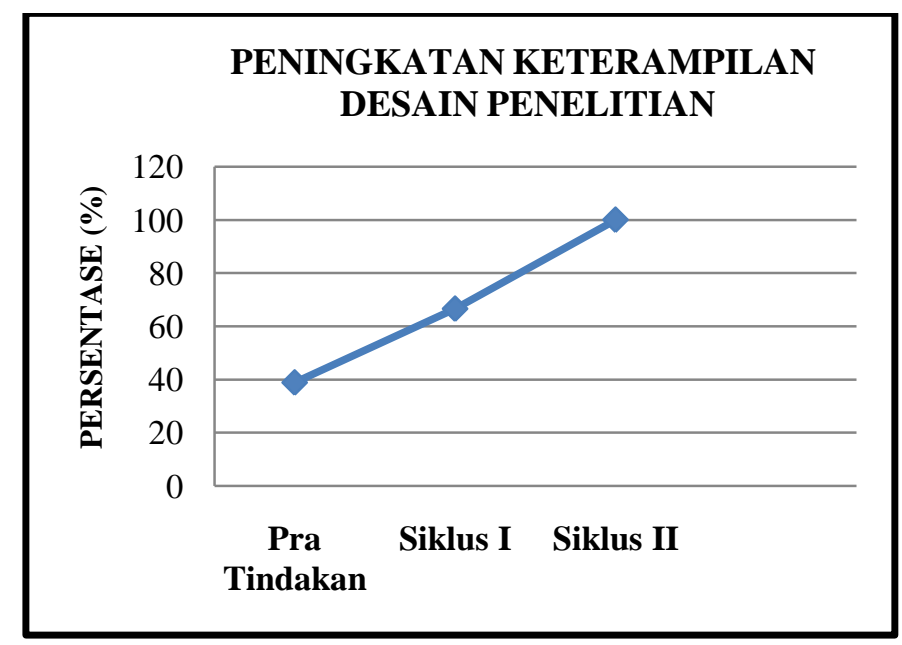

Penerapan pembelajaran Group Investigation (GI) dalam meningkatkan keterampilan penulisan desain penelitian terlihat dari proses pembelajaran yang dilaksanakan dosen. Proses pembelajaran secara keseluruhan terlaksana dengan baik dari mulai tahap pendahuluan, inti, dan penutup. Dosen memaksimalkan untuk menggali kemampuan mahasiswa yang kaitannya dengan peningkatan keterampilan mahasiswa dalam menulis desain penelitian. Untuk dapat menulis desain penelitian mahasiswa harus memiliki sikap dan pemikiran ilmiah dalam upaya meningkatkan keterampilan menulis desain penelitian.

Hal ini sejalan dengan pendapat dalam jurnal yang ditulis oleh Istikomah dkk (2010: 43) bahwa model pembelajaran dapat menumbuhkan sikap ilmiah pada peserta didik. Pembelajaran pada kelas memberikan kesempatan kepada peserta didik untuk mengalami sendiri aktivitas dan pengalaman dalam belajar secara nyata. Mereka memperoleh informasi dengan mengkonstruksi sendiri dari data-data yang didapatkannya. Model pembelajaran Group Investigation (GI) memberikan peningkatan dalam menulis keterampilan berpikir.

Pada pra tindakan, mahasiswa masih banyak yang belum masuk dalam kriteria tuntas dalam menulis desain penelitian dengan presentase sebesar 38,9\%. Hal ini terjadi sebagai gambaran bahwa masih banyak mahasiswa yang belum 
secara utuh memahami penulisan desain penelitian. Padahal pada semester sebelumnya telah mendapat mata kuliah yang relevan dengan penulisan desain penelitian. Siklus I, kelas A sore Semester 6 mendapatkan perolehan presentase sebesar $66,6 \%$. Presentase tersebut belum mencapai indikator kinerja minimum sebesar $75 \%$. Namun ada peningkatan $27,7 \%$ walaupun tidak secara signifikan. Hal ini terjadi karna model pembelajaran Group Investigation mampu membangun pengetahuan secara bersama-sama sehingga memudahkan mahasiswa untuk bertukar pengetahuan dengan sesama teman di kelas. Presentasi yang dilakukan dalam bentuk Seminar Desain juga turut ambil bagian dalam membangun pengetahuan mahasiswa. Hal tersebut sejalan dengan pendapat yang dikemukan oleh Slavin (2005: 215) sebagai berikut :

"Group investigation merupakan sebuah pembelajaran kooperatif yang menuntut dialog interpersonal dan dimensi rasa sosial. Intelektual dapat dibangun bersama-sama kelompok. Kelompok sebagai sumber-sumber penting bagi peserta didik untuk belajar. Oleh karena itu peran teman satu kelas yang dibagi menjadi kelompok-kelompok kecil turut andil dalam pertukaran intelektual".

Peningkatan terlihat semakin nyata pada siklus II dimana keunggulan dari model pembelajaran Group investigation dapat meningkatakan presentase ketuntasan mahasiswa menjadi $100 \%$. Semua mahasiswa mampu menulis desain penelitian dengan segala kriteria yang ada. Namun masih banyak perbaikan yang dilakukan untuk dapat meningkatkan keterampilan mahasiswa dalam menulis desain penelitian di masa yang akan datang.

\section{SIMPULAN}

Pelaksanaan pembelajaran melalui penerapan Model Pembelajaran Group Investigation. Hasil yang diperoleh dari Lembar IPKG II diperoleh bahwa penerapan model pembelajaran yang dilakukan dosen baik sekali. Peningkatan kepercayaan diri mahasiswa mulai pra tindakan sampai pada siklus I sebesar 27,7\% dan mulai siklus I sampai pada siklus II sebesar 33,4\%. Walaupun peningkatannya tidak signifikan namun cukup membawa dampak positif terhadap keterampilan penulisan desain penelitian mahasiswa sehingga dapat ikut 
membantu dalam menyiapkan mahasiswa dalam proses penulisan skripsi diakhir masa studi.

\section{DAFTAR PUSTAKA}

Hamdani. 2011. Strategi Belajar Mengajar. Bandung : Pustaka Setia.

Indajati \& Ahmad Jamalong. 2017. Peningkatan Hasil Belajar Pendidikan Kewarganegaraan Melalui Penerapan Metode Group Investigation. Sosial Horizon : Jurnal Pendidikan Sosial Vol.4 No.1 Hal 97-110.

Istikomah, H, dkk. 2010. Penggunaan Model Pembelajaran Group Investigation Untuk Menumbuhkan Sikap Ilmiah Siswa. Jurnal Pendidikan Fisika Indonesia 6: 40-43.

Jihad, Asep \& Haris, Abdul. 2013. Evaluasi Pembelajaran. Yogyakarta : Multi Prssindo.

Kurniasih, Imas dan Sani, Berlin. 2015. Ragam Pengembangan Model Pembelajaran Untuk Peningkatan Profesionalitas Guru. Jakarta : Kata Pena.

Slavin, Robert E. 2005. Cooperative Learning : Teori, Riset dan Praktik. Bandung: Nusa Media.

Sudjana, Nana. 2016. Penilaian Hasil Proses Hasil Belajar Mengajar. Bandung : Remaja Rosdakarya.

Undang-undang Republik Indonesia Nomor 12 Tahun 2012 tentang Pendidikan Tinggi. 